\title{
Accuracy of Root ZXII, E-PEX and FIND apex locators in teeth with vital pulp: an in vivo study
}

\author{
Marina Tolomei Sandoval CURY(a) \\ Ana Maria Veiga VASQUES(a) \\ Carlos Roberto Emerenciano BUENO(b) \\ Thiago MACHADO(a) \\ Juliana Quintino TRIZZI(a) (D) \\ Vitor da Silva SANTANA(a) (D) \\ Eloi DEZAN-JÚNIOR(a) (D) \\ (a) Universidade Estadual Paulista "Júlio de \\ Mesquita Filho" - Unesp, Araçatuba. School \\ of Dentistry, Department of Endodontics, \\ Araçatuba, SP, Brazil. \\ (b) Universidade Estadual do Norte do Paraná \\ - UENP, School of Dentistry, Department of \\ Endodontics, Jacarezinho, PR, Brazil.
}

Declaration of Interests: The authors certify that they have no commercial or associative interest that represents a conflict of interest in connection with the manuscript.

\section{Corresponding Author:}

Eloi Dezan-Junior

E-mail: dezan@foa.unesp.br

hitps://doi.org/10.1590/1807-3107bor-2021.vol35.0080

Submitted: March 18, 2020

Accepted for publication: November 11, 2020

Last revision: February 8, 2020
Abstract: This research evaluated, in vivo, the accuracy of three electronic apex locators - EALs (Root ZXII, E-PEX and FIND) in teeth with vital pulp submitted to biopulpectomy, preserving the periodontal stump. For this study, 90 single-rooted teeth with extraction indication were selected. After positive pulpal cold sensitivity test, pulp chamber access was performed. The cervical and middle thirds of root canals were instrumented with Reciproc R25, and the K\#15 file was used as a standard instrument to determine working length, forming 2 groups: Constriction (insertion of the instrument until the apical constriction limit) and Foramen (insertion of the instrument until the foramen and then repositioning at constriction, without removing the file from the canal). The hand file was stabilized with a light-cured flow resin. After extraction, the samples were analyzed through microCT SkyScan 1272, with CTAN software, which evaluated the proximity between the tip of the file to the apical constriction, providing data for comparative analysis using Kruskal-Wallis and Dunn tests $(p<0.05)$. There was a statistically significant difference in the abilities of the EALs to detect the apical constriction after reaching the foramen with Root ZX II showing higher accuracy (89\%). However, there was no difference in the accuracy of the three EALs in detecting the apical constriction without reaching the foramen. Based on the present results, we conclude that EALs may show accurate measures in detecting apical constriction and foramen, even without damaging the periodontal stump in biopulpectomy.

Keywords: Endodontics; Dental Instruments; Odontometry; Tooth Apex.

\section{Introduction}

The importance of an accurate work length determination, from a biological perspective, is to restrict the biomechanical instrumentation inside root canals, without unnecessary damage to periapical tissue, leading to a milder inflammatory reaction and a decrease in postoperative discomfort ${ }^{1}$ when compared with instrumentation beyond root canal. ${ }^{2} \mathrm{~A}$ conventional way to determine work length during odontometry is using the radiographic Ingle technique. Although this method is still used, it allows image misinterpretation, since radiography is a two-dimensional image of a three dimensional structure, making it difficult to accurately 
determine apical/foramen limit, besides overlapping images of anatomical structures. ${ }^{3}$

The apical constriction is the narrow diameter inside the root canal that often coincides with the cemento-dentin junction, located 1 to $2 \mathrm{~mm}$ short of the apical foramen, ${ }^{4}$ frequently standardized as a limit for endodontic instrumentation and obturation. ${ }^{5}$ The exit position of apical foramen is often lateral to the root apex. In a tomographic study with 1400 teeth, Estrela et al. ${ }^{3}$ observed that the apical foramen is found more frequently in central position in the upper central incisors (60\%), vestibular in the lower central incisors (44\%) and distal in superior lateral incisors (31\%). Those reports evidenced the difficult to detect the apical limit to determine working length with conventional radiographic, because the lack of coincidence between foramen exit and radiographic vertex.

Errors related to working length can lead to overinstrumentation and consequent overfilling, inducing the formation of granulomas, impairing the outcome of endodontic treatment, since cytotoxic effects of obturating materials can induce postoperative pain and even persistence of the inflammatory process. ${ }^{6,7,8}$ In biopulpectomy, the biological philosophy preserves the vitality of the invaginated periodontal tissue inside the cemental canal (periodontal stump) aiming a periapical repair process. ${ }^{9,10}$

Endodontic literature suggests that the consistency and accuracy of the electronic apex locators (EALs) function may vary in the apical foramen and the apical constriction. ${ }^{11}$ The root canal dentin walls have low electrical conductivity capacity. However, near the apical third, dentin becomes thinner, reducing electrical insulation (impedance of $0.72 \mathrm{~W}$, approximately $1 \mathrm{~mm}$ short of the apical foramen) $)^{12}$ and maintaining electrical resistance constant and unaltered by factors, such as dental anatomy, canal diameter or presence of periapical pathologies. ${ }^{13}$

The Root ZX II (J Morita Corp., Tokyo, Japan), created in 1992, was the first apex locator with the ability to work on wet root canals, simultaneously measuring the impedance values at two different frequencies ( 0.4 and $8.0 \mathrm{kHz}$ ) by calculating the quotient with a precision of $96.2 \%$ and automatic calibration. ${ }^{14}$
Released in mid of 2014, FIND (Ultradent, South Jordan, USA) is an EAL that uses a multifrequency impedance method to accurately determine the position of the apical foramen. According to the manufacturer, extremely dry root canals may jeopardize the EAL precision, which may be overcome by filling root canals with electrolytic solutions, such as sodium hypochlorite, to improve electrical conductivity. ${ }^{15}$

The recently released E-PEX (MK Life, Porto Alegre, Brazil) also works by impedance ratio from the $4^{\text {th }}$ EALs generation. The manufacturer claims that when blood is present inside the root canal, readings may be inaccurate.

Due to the lack of in vivo studies regarding performance of EALs in biopulpectomy preserving the periodontal stump, the aim of this study was to evaluate the accuracy EALs in detect the apical constriction with and without reaching the apical foramen.

\section{Methodology}

The study was approved by the Research Ethics Committee - CAAE: 62813816.3.0000.5420.

Adopting a sample power of $80 \%$ and a value of $\mathrm{p}<0.05,13$ teeth per group would be necessary. Taking into account possible loss of specimens, we added 2 elements per group.

Ninety vital single-rooted teeth were selected with extraction indication for prosthetic or orthodontic reasons ${ }^{11}$ whose patients voluntarily sought the dental service of Araçatuba School of Dentistry, encompassing: 10 upper central incisors, 13 upper lateral incisors, 12 upper canines, 10 lower central incisors, 14 lower lateral incisors, 16 lower canines, 10 first lower premolars and 5 lower premolars. Teeth with necrotic pulp, multi-rooted teeth, calcified canals, fractured root, apical resorption, endodontic treatment, incomplete rhizogenesis, that shows less than $5 \mathrm{~mm}$ of bone insertion, residual root and patients with pacemakers were excluded from the study.

All teeth were previously submitted to initial digital radiographic (Micro Imagem, Indaiatuba, Brazil) followed by a pulp sensitivity test with endo ice spray (Maquira, Maringá, Brazil)..$^{15}$ 
Under anesthesia with mepivacaine $2 \%$ (Mepiadre, 2\% epinephrine 1: 100.000, Nova DFL) and rubber dam isolation, the pulp chamber was accessed with a high- speed 1557 carbide drill and 3082 diamond tip (Microdont, São Paulo, Brazil). After locating the canal orifice with a hand file K\#15 (Dentsply Maillefer, USA), the pulp tissue was removed. Reciproc R25 was used to perform biomechanical preparation of the cervical and middle thirds, ${ }^{16}$ and the canals were irrigated with $2 \mathrm{~mL}$ of $1 \%$ sodium hypochlorite (Cloro rio, Rio de Janeiro, Brazil).

After removal of cervical and middle dentinal interference and aspiration of pulp chamber, the $25 \mathrm{~mm}$ file $\mathrm{K \#} 15^{17}$ was re-inserted in the canal and then, attached to the EAL, forming two experimental groups, without removing the file from the canal:

Foramen group: the file was introduced in a twostep movement: reaching the foramen ("APEX" or mark 0.0) and then retreating and repositioning at the apical constriction (without removing the instrument from the canal), as determined by the EALs (mark 0.5);

Constriction group: the file was introduced in single-step movement: insertion of instrument until EALs indication of apical constriction (mark 0.5), without reaching the foramen (mark 0.0).

The data measurement was accepted after 5 seconds of stability, ${ }^{18}$ and the hand file was stabilized with flowable resin (Filtek Z350 XT Flow - 3M ESPE) by filling cervical and middle third and photopolymerized for 60 seconds (Kavo, with light intensity $1100 \mathrm{~mW} / \mathrm{cm}^{2}$ ). Then, metal handle was cut with a diamond bur to facilitate extraction, without risks of moving the instrument.

Teeth were extracted and immersed in 5.25\% sodium hypochlorite for 10 minutes to remove remaining organic tissues and stored in saline solution.

A total of 8 incisors, 3 canines and 4 premolars were used with the E-PEX in the Foramen group, and in the Constriction group, 7 incisors, 4 canines and 3 premolars. The FIND encompassed in the Foramen group, 6 incisors, 5 canines and 3 premolars, and in the Constriction group, 7 incisors, 5 canines and 3 premolars. The Root ZXII had 7 incisors, 4 canines and 1 premolar in the Foramen group and 5 incisors, 7 canines and 1 premolar in the Constriction group.

The samples were scanned with microtomography Skyscan (SkyScan 1272 Bruker MicroCT, Aartselaar, Belgium, 2003), and with the aid of Data Viewer (SkyScan, Versão 1.4.4 64- bit, Aartselaar, Belgium) image DATA was emulated on $\mathrm{X}, \mathrm{Y}$ and $\mathrm{Z}$ axis.

The generated images were measured from the center of foramen to the tip of the endodontic file; and from the tip of the file to the center of the constriction. All measurements were performed by the same experienced and calibrated operator, eliminating the possibility of bias.

The data were submitted to statistical analysis (SigmaPlot 12.0, Systat software, Inc., Chicago, USA). After Shapiro-Wilk normality test, Kruskal-Wallis and Dunn tests were performed with a significance level of $5 \%(p<0.05)$

\section{Results}

Seven teeth were excluded from the study because of root fracture during extraction. In the foramen group, a statistical difference (Figure 1) was observed in the accuracy of the Root ZX II, with a more accurate precision (89\%) in identifying the constriction compared to the FIND $(61,8 \%)$ and E-PEX $(80,9 \%)(p=0.005)$, when the file reached the foramen (mark 0.0) and was repositioned at constriction (mark $0.5)$, but without difference between E-PEX and FIND $(p>0.05)$. Regarding the constriction group, there was no statistical difference between the EALs ( $p>0.05)$, when detecting the constriction (mark 0.5) without reaching foramen.

On EPEX locator foramen group, the tip of the file distanced from the foraminal constriction, on average, $0.575 \mathrm{~mm}$ and $0.191 \mathrm{~mm}$ in the constriction group. With respect to FIND, the tip of the file distanced $0.382 \mathrm{~mm}$ from the constriction in the foramen group and $0.224 \mathrm{~mm}$ in the constriction group. For the Root ZX II, the tip of the file distanced, on average, $0.11 \mathrm{~mm}$ from constriction in the foramen group and $0.047 \mathrm{~mm}$ in the constriction group (Figure 2).

The distance from the tip of the file to the center of the foramen was, on average, $0.623 \mathrm{~mm}, 0.435$ 


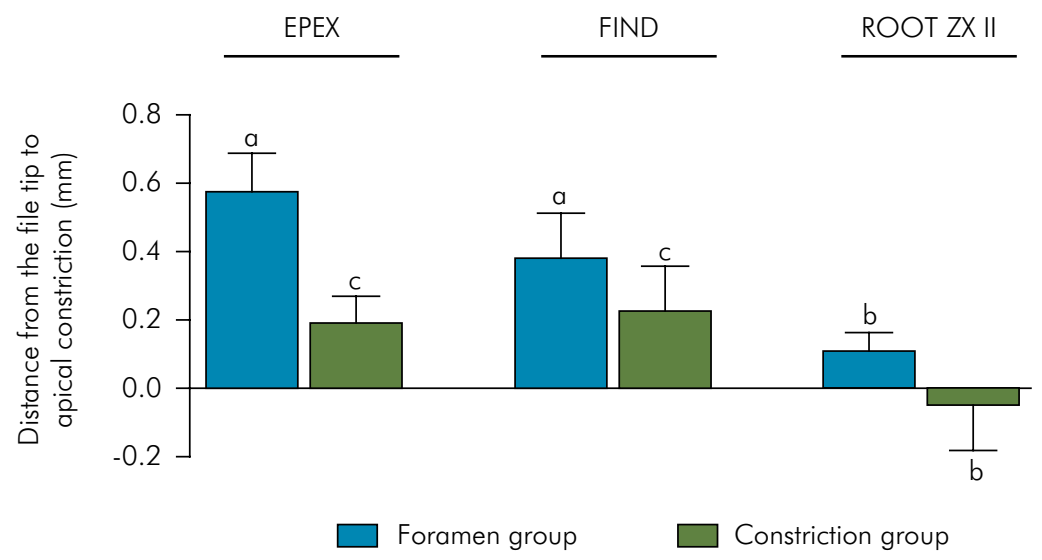

Figure 1. Distances $(\mathrm{mm})$ recorded from the tip of the endodontic file to the apical constriction. Different letters indicate statistical difference $(p<0.05)$

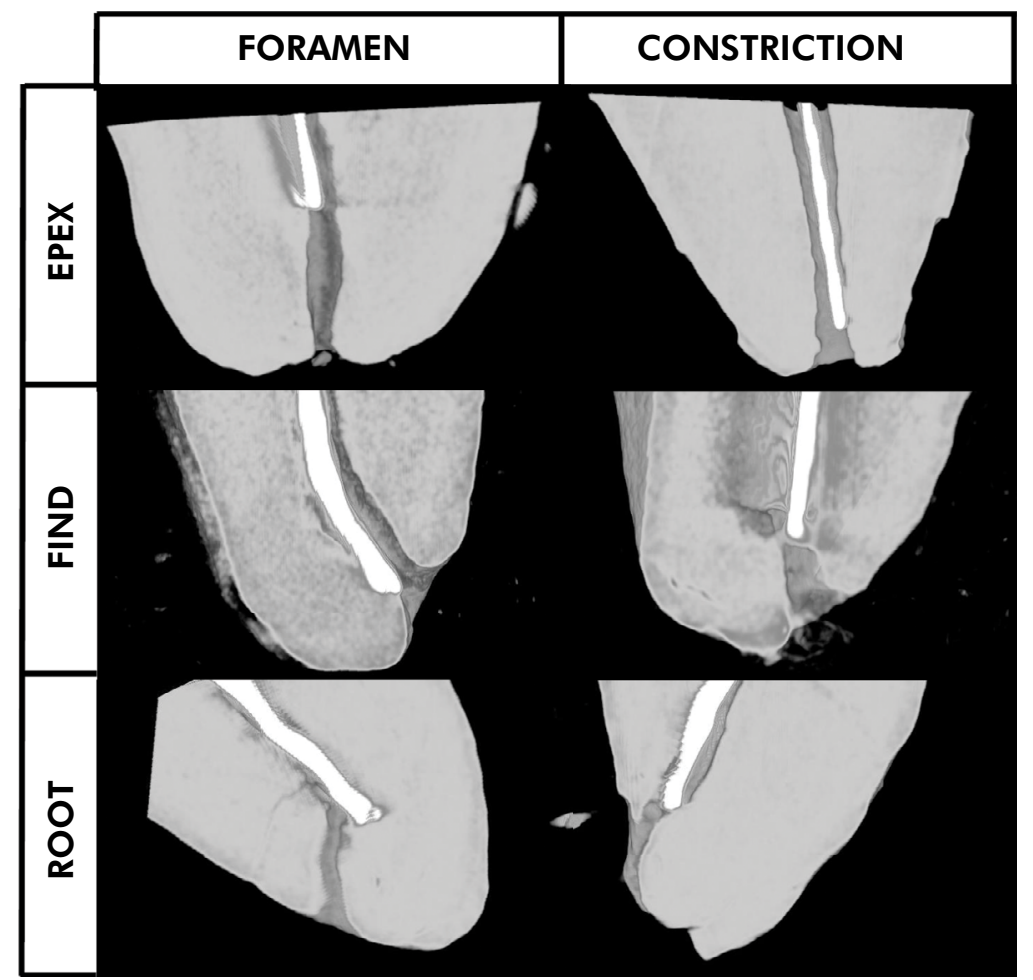

Figure 2. Representative images of the distance between the tip of the file and the constriction in Foramen group and Constriction group $(9 \mu \mathrm{m}$, magnification of $52 \mathrm{x})$.

$\mathrm{mm}$ and $0.513 \mathrm{~mm}$ for E-PEX, FIND and Root ZX II respectively, in foramen groups. In constriction groups, the distance from the tip of the file to the center of the foramen was, on average, $0.450 \mathrm{~mm}$, $0.817 \mathrm{~mm}$ and $0.483 \mathrm{~mm}$, for E-PEX, FIND and Root ZX II, respectively.

\section{Discussion}

The use of EALs in biopulpectomy may be impaired by the presence of vital tissue inside root canal, as the periodontal stump. Therefore, during odontometry, it has been preconized the 
introduction of the hand file until the 0.0 mark in the EAL, which corresponds to the apical foramen, to obtain a more accurate measure. ${ }^{18}$ Thus, in order to evaluate this necessity of periodontal stump injury to obtain accurate root canal length, this study analyzed in vivo the EALs accuracy in locating apical constriction in biopulpectomy, by reaching or not the foramen. According to our results, there was no difference in EALs precision regarding maintaining the periodontal stump intact, showing high reliability results in the detection of the foraminal constriction.

MicroCT systems are widely used in endodontics to analyze the presence of anatomical structures, variations, ${ }^{19}$ and lesions, ${ }^{20}$ among several other indications. In the present study, it was critical to accurately verify the position of the tip of the file in the apical third of the root canal. Therefore, we preferred the use of tomography due to its superior image quality and precision of analysis, when compared to conventional radiographic techniques. ${ }^{21,22}$ With microCT scans, it was even possible to visualize mean apical constriction diameters of $0.296 \mathrm{~mm}$ (approximately). ${ }^{23}$

The rationale of endodontic treatment is to conserve the vitality of the periodontal stump in biopulpectomy and stimulate repair with the formation of a biological seal. ${ }^{9,10}$ Therefore, this study used teeth with extraction indication for prosthetic or orthodontic reasons, which responded positively to the sensitivity cold test, indicating the presence of vital pulp tissue.

The results obtained in the constriction group showed accuracy in locating constriction without reaching the apical foramen first, contrasting a previous ex vivo study, ${ }^{24}$ which demonstrated that not reaching the apical foramen (mark 0.0) during odontometry interferes in the interpretation of the resistive factor, one of the components of the impedance calculated by foramen locators.

Previous studies have showed that EALs often present inaccurate results, when fluids and blood are present in the root canal, ${ }^{25,26}$ assuming that a root canal with vital tissue may demonstrate a different impedance compared to a necrotic one. It is important to note that those studies used previous generations of EALs that had limitations on accuracy.

The pulp removal results in bleeding inside the root canal. Since blood is electrolyte, it may influence the accuracy of EALs. Saatchi et al. ${ }^{26}$ reported that the accuracy of Root ZX decreased slightly in the presence of blood in the root canal. In a study with 36 extracted teeth, Ebrahim et al. ${ }^{27}$ observed that in the presence of sodium hypochlorite, the apex locator Root ZX II was more accurate, than when used in a root canal filled with blood.

Corroborating previous reports, ${ }^{28,29}$ our results showed that the presence of a vital pulp did not influence the accuracy of EALs, regarding the detection of the apical constriction, since the results showed no difference in detecting the constriction (mark 0.5), without reaching foramen.

From a biological perspective, in cases of vital pulp, the preservation of the vitality of the connective tissue located in the cementum portion of the root canal, improves the healing process and apical closure by deposition of neoformed cementum., ${ }^{910}$ Instrumentation, beyond apical constriction, injuries the periodontal stump, which is replaced by a blood clot, hindering the repair process. ${ }^{28}$

The preservation of the periodontal stump was also emphasized by Holland et al. ${ }^{30}$ which performed a study in dogs with vital pulp tissue and observed that the specimens which the periodontal stump was preserved without patency, yielded better results for the process of periapical repair, besides offering some resistance to the extrusion of obturating material.

\section{Conclusions}

The results suggest that it is not necessary to reach the apical foramen during odontometry in cases of biopulpectomy to obtain accuracy of the EALs, maintaining the vitality and integrity of the periodontal stump.

\section{Acknowledgments}

This research was supported by Coordenação de Aperfeiçoamento de Pessoal de Nível Superior (CAPES). 


\section{References}

1. Harrison JW, Baumgartner JC, Svec TA. Incidence of pain associated with clinical factors during and after root canal therapy. Part 2. Postobturation pain [Oct.]. J Endod. 1983 Oct;9(10):434-8. https://doi.org/10.1016/S0099-2399(83)80259-3

2. Siögren U, Hagglund B, Sundqvist G, Wing K. Factors affecting the long-term results of endodontic treatment. J Endod. 1990 Oct;16(10):498-504. https://doi.org/10.1016/S0099-2399(07)80180-4

3. Estrela C, Couto GS, Bueno MR, Bueno KG, Estrela LR, Porto OC, et al. Apical foramen position in relation to proximal root surfaces of human permanent teeth determined by using a New Cone-beam Computed Tomographic Software. J Endod. 2018 Nov;44(11):1741-8. https://doi.org/10.1016/i.joen.2018.07.028

4. Dummer PM, McGinn JH, Rees DG. The position and topography of the apical canal constriction and apical foramen. Int Endod J. 1984 Oct;17(4):192-8. https://doi.org/10.1111/j.1365-2591.1984.tb00404.x

5. Wolf TG, Paqué F, Sven Patyna M, Willershausen B, Briseño-Marroquín B. Three-dimensional analysis of the physiological foramen geometry of maxillary and mandibular molars by means of micro-CT. Int J Oral Sci. 2017 Sep;9(3):151-7. https://doi.org/10.1038/ijos.2017.29

6. Seltzer S, Naidorf IJ. Flare-ups in endodontics: II. Therapeutic measures. 1985. J Endod. 2004 Jul;30(7):482-8. https://doi.org/10.1097/00004770-200407000-00006

7. Rambo MV, Gamba HR, Borba GB, Maia JM, Ramos CA. In vivo assessment of the impedance ratio method used in electronic foramen locators. Biomed Eng Online. 2010 Sep;9(1):46. https://doi.org/10.1186/1475-925X-9-46

8. Dezan E, Holland R, Consolaro A, Ciesielski Fl, Jardim EG. Experimentally induced anachoresis in the periapical region after root canal filling. Int J Odontostomatol. 2012 Apr;6(1):5-10. https://doi.org/10.4067/S0718-381X2012000100001

9. Holland R, Souza V. Ability of a new calcium hydroxide root canal filling material to induce hard tissue formation. J Endod. 1985 Dec;11(12):535-43. https://doi.org/10.1016/S0099-2399(85)80199-0

10. Holland R, Souza V, Nery MJ, Mello W, Bernabé PF, Otoboni Filho JA. Effect of the dressing in root canal treatment with calcium hydroxide. Rev Fac Odontol Aracatuba. 1978;7(1):39-45.

11. Connert T, Judenhofer MS, Hülber-J M, Schell S, Mannheim JG, Pichler BJ, et al. Evaluation of the accuracy of nine electronic apex locators by using Micro-CT. Int Endod J. 2018 Feb;51(2):223-32. https://doi.org/10.1111/iej.12814

12. Nekoofar MH, Ghandi MM, Hayes SJ, Dummer PM. The fundamental operating principles of electronic root canal length measurement devices. Int Endod J. 2006 Aug;39(8):595-609. https://doi.org/10.1111/j.1365-2591.2006.01131.x

13. Suzuki K. Experimental study in iontophoresis. J Jap Stomat Soc. 1942 Aug;16:414-7.

14. Angwaravong $O$, Panitvisai P. Accuracy of an electronic apex locator in primary teeth with root resorption. Int Endod J. 2009 Feb;42(2):115-21. https://doi.org/10.1111/j.1365-2591.2008.01476.x

15. Parente LA, Levin MD, Vivan RR, Bernardes RA, Duarte MA, Vasconcelos BC. Efficacy of electronic foramen locators in controlling root canal working length during rotary instrumentation. Braz Dent J. 2015 Oct;26(5):547-51. https://doi.org/10.1590/0103-6440201300099

16. Tennert C, Herbert J, Altenburger MJ, Wrbas KT. The effect of cervical preflaring using different rotary nickel-titanium systems on the accuracy of apical file size determination. J Endod. 2010 Oct;36(10):1669-72. https://doi.org/10.1016/i.joen.2010.06.017

17. Briseño-Marroquín B, Frajlich S, Goldberg F, Willershausen B. Influence of instrument size on the accuracy of different apex locators: an in vitro study. J Endod. 2008 Jun;34(6):698-702. https://doi.org/10.1016/i.joen.2008.02.019

18. Aguiar BA, Reinaldo RS, Frota LM, Vale MS, Vasconcelos BC. Root ZX electronic foramen locator: an ex vivo study of its three models' precision and reproducibility. Int J Dent. 2017;2017(Mar):5893790. https://doi.org/10.1155/2017/5893790

19. Kalatzis-Sousa NG, Spin-Neto R, Wenzel A, Tanomaru-Filho M, Faria G. Use of micro-computed tomography for the assessment of periapical lesions in small rodents: a systematic review. Int Endod J. 2017 Apr;50(4):352-66. https://doi.org/10.1111/iej.12633

20. Deliga Schröder AG, Westphalen FH, Schröder JC, Fernandes Â, Westphalen VP. Accuracy of digital periapical radiography and cone-beam computed tomography for diagnosis of natural and simulated external root resorption. J Endod. 2018 Jul;44(7):1151-8. https://doi.org/10.1016/j.joen.2018.03.011

21. Dudic A, Giannopoulou C, Martinez M, Montet X, Kiliaridis S. Diagnostic accuracy of digitized periapical radiographs validated against micro-computed tomography scanning in evaluating orthodontically induced apical root resorption. Eur J Oral Sci. 2008 Oct;116(5):467-72. https://doi.org/10.1111/j.1600-0722.2008.00559.x

22. O’Neill LJ. A clinical evaluation of electronic root canal measurement. Oral Surg Oral Med Oral Pathol. 1974 Sep;38(3):469-73. https://doi.org/10.1016/0030-4220(74)90376-4

23. Herrera M, Abalos C, Planas AJ, Llamas R. Influence of apical constriction diameter on Root ZX apex locator precision. J Endod. 2007 Aug;33(8):995-8. https://doi.org/10.1016/i.joen.2007.05.009 
24. Kim Y, Chang SW, Lee JK, Chen IP, Kaufman B, Jiang J, et al. A micro-computed tomography study of canal configuration of multiple-canalled mesiobuccal root of maxillary first molar. Clin Oral Investig. 2013 Jul;17(6):1541-6. https://doi.org/10.1007/s00784-012-0852-8

25. Inoue N. Dental "stethoscope" measures root canal. Dent Surv. 1972 Jan;48(1):38-9.

26. Saatchi M, Aminozarbian MG, Noormohammadi H, Baghaei B. Influence of blood on the accuracy of Raypex 5 and Root ZX electronic foramen locators: an in vivo study. Braz Dent J. 2016 May-Jun;27(3):336-9. https://doi.org/10.1590/0103-6440201600678

27. Ebrahim AK, Yoshioka T, Kobayashi C, Suda H. The effects of file size, sodium hypochlorite and blood on the accuracy of Root ZX apex locator in enlarged root canals: an in vitro study. Aust Dent J. 2006 Jun;51(2):153-7. https://doi.org/10.1111/j.1834-7819.2006.tb00419.x

28. Holland R, Nery MJ, Mello W, Souza V, Bernabé PF, Otoboni Filho JA. Root canal treatment with calcium hydroxide. II. Effect of instrumentation beyond the apices. Oral Surg Oral Med Oral Pathol. 1979 Jan;47(1):93-6. https://doi.org/10.1016/0030-4220(79)90109-9

29. ElAyouti A, Dima E, Ohmer J, Sperl K, Ohle C, Löst C. Consistency of apex locator function: a clinical study. J Endod. 2009 Feb;35(2):179-81. https://doi.org/10.1016/i.joen.2008.10.017

30. Holland R, Sant'Anna Júnior A, Souza V, Dezan Junior E, Otoboni Filho JA, Bernabé PF, et al. Influence of apical patency and filling material on healing process of dogs' teeth with vital pulp after root canal therapy. Braz Dent J. 2005;16(1):9-16. https://doi.org/10.1590/S0103-64402005000100002 